International Journal of Linguistics, Literature and Translation

ISSN: 2617-0299 (Online); ISSN: 2708-0099 (Print)

DOI: 10.32996/ijltt

Journal Homepage: www.al-kindipublisher.com/index.php/ijltt

\title{
Investigating the Effect of Blended Learning on Iranian EFL Learners' Autonomy, Self- esteem, and Vocabulary Achievement
}

\author{
Parisa Aalinezhad 1 8(D) $\triangle$, Zohreh Salehan² 8(D), Zohreh Noroozi ${ }^{3}$ (D) \\ ${ }^{1}$ English Department, Islamic Azad University, Shahreza Branch, Isfahan, Iran \\ 2Islamic Azad University, Shahreza Branch, Isfahan, Iran \\ 3Islamic Azad University, Ardebil Branch, Ardebil, Iran
}

$\triangle$ Corresponding Author: Parisa Aalinezhad, E-mail: p.aalinezhad90@gmail.com

\section{ARTICLE INFORMATION}

Received: May 08, 2021

Accepted: June 14, 2021

Volume: 4

Issue: 6

DOI: $10.32996 /$ ijllt.2021.4.6.18

\section{KEYWORDS}

Blended Learning, Face-to-Face Learning, Autonomy, Self-esteem, and Vocabulary Achievement

\section{ABSTRACT}

This study aimed at examining the influence of blended learning on Iranian English as Foreign Language (EFL) learners' autonomy, self-esteem, and vocabulary achievement. To do this, 60 Iranian females intermediate EFL learners were chosen from an institute in Ilam, Iran. Then, the selected participants were divided into two groups; one experimental group (EG) and one control group (CG). Each group contained 30 learners. Afterwards, in three separate sessions, the instruments of learner autonomy, self-esteem, and vocabulary progress were distributed and administered among the participants of both groups. The researchers offered a blended learning teaching framework to the EG to encourage students to utilize the language in and out of the classroom. The target vocabulary was learnt by the learners using blended learning techniques. While the same vocabularies were learned through the face-to-face way of instruction in the CG. After the period of teaching that lasted for 6-weeks, the participants of both groups received the learner autonomy, self-esteem, and vocabulary achievement instruments as post-test. The results demonstrated that instruction through a blended learning approach had a considerable impact on participants' level of autonomy and vocabulary achievement. But the approach had no significant impact on learners' self-esteem. EFL learners, Teachers, and material developers can benefit from the results of the study.

\section{Introduction}

The contemporary era is distinguished by rapid changes as a result of scientific and technological developments, including information technology. Keeping up with these changes is crucial in the educational system to overcome issues that may occur as a result of them, such as wider coverage of the knowledge and an increase in the number of learners, along with instructor failures. These technological advancements brought in a plethora of modern learning processes and teaching, such as e-learning and blended learning, particularly in studies and self-advancement domains (Mousa \& Mubarak, 2005), as well as an uprising in digital technologies, which has turned the world into a global village. The former resulted in a greater demand for learners to interact in enterprise application environments, while the latter resulted in learners sharing their knowledge with others.

The issue of blended learning has been around for a long period, but its terminology was not firmly established until around the beginning of the 21st century. According to Graham (2006) blended learning systems can be defined as systems of learning that combine computer-mediated teaching with face-to-face teaching. Most scholars who have investigated the approach of blended learning and its place in promoting vocabulary knowledge list many positive impacts. Zhang, Song, and Burston (2011), and Khazaei and Dastjerdi (2011) conducted comparative research on the influence of traditional and blended instruction on the EFL learners' vocabulary learning. The results indicated that the learners who received the content of learning via the blended learning approach outperformed the group of learners who received the content of learning traditionally.

\section{K C AL-KINDI CENTER $\mathbf{R}$ D FOR RESEARCH AND DEVELOPMENT}

Your gateway to world-class research

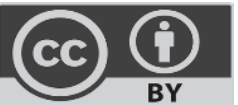

Published by Al-Kindi Center for Research and Development, London, United Kingdom. Copyright (c) the author(s). This open access article is distributed under a Creative Commons Attribution (CC-BY) 4.0 license 
It is believed that several concepts such as learner's self-esteem and autonomy may be influence by the modern approaches of teaching such as blended learning. Self-esteem is viewed as one of the significant fundamental components as the achievement or failure of an individual relies greatly on one's self-esteem level (Namaziandost, Rezvani, \& Polemikou, 2020). According to Stevick (1990), success is determined less by methodologies, linguistic assessment, and resources and more by what happens within and between individuals in the course. It is considered that success is measured not by how much one gets, but by how pleased one is with his job (Grandin, 2002). As a result, an individual must put a high priority on his achievement and be optimistic in his progression since the decisions he makes are the impetus for developing competency (Stout, 2001). Furthermore, Branden (1985) showed that the most important obstacle to progression is not the non-existence of talent or ability or but it is the non-existence of self-esteem.

It seems that the issue of autonomy may be affected by some new approaches of teaching that are learner-centered. In the history of education. The motivation for autonomous learning is not a new key component. Learner autonomy, as a relatively new field of research, has progressively evolved since the $1970 \mathrm{~s}$ as a result of a new breed of enthusiasm in active learning research papers: students have increasingly been taken into consideration as language makers rather than as learners of a system imposed by society (Bocanegra \& Haidi, 1999; Namaziandost, Nasri, \& Ziafar, 2019). Learner autonomy is seen as one of the critical factors determining whether a person achieves or misses the mark of his or her ability. As a result, the purpose of this study is to look at the impact of blended learning on the autonomy, self-esteem, and vocabulary development of Iranian EFL learners.

\subsection{Purpose of the Study}

There is a requirement for evidence that utilizing blended learning has a strong impact in promoting the outcomes of learning, particularly advancement in learning vocabulary. The goal of the research is to examine the influence of blended learning on Iranian EFL learners' vocabulary achievement. In addition, the objective of the research is to examine the usefulness of blended learning on learners' level of autonomy and self-esteem.

\subsection{Research Questions}

The present study tries to investigate the following questions:

1. Does blended learning have a significant effect on Iranian EFL learners' autonomy?

2. Does blended learning have a significant effect on Iranian EFL learners' self-esteem?

3. Does blended learning have a significant effect on Iranian EFL learners' vocabulary achievement?

\section{Literature Review}

Numerous researchers who have investigated the approach of blended learning on improving vocabulary knowledge reported several positive impacts. Zhang, Song, and Burston (2011) performed comparative research on the effectiveness of learning vocabulary through smartphones and made a comparison between two groups of learners at a Chinese university. According to the findings, students could acquire language more effectively and successfully with smartphones than they did use paper materials.

In another study, Alshwiah (2009) examined the impact of the blended learning technique and assessed learners' attitudes toward the English language at Arabian Gulf University. Respondents were categorized into two groups: control and experimental. There was no discernible difference between the two groups in terms of advancement or attitudes toward the English language, according to the data.

Many researchers (Apter, 1998; Branden, 1999; Murk, 1999; Namaziandost, \& Çakmak, 2020) viewed self-esteem as one's subjective opinion, judgment, and personal attitude toward oneself. If it is negative, it leads to troubles and low academic progression. When this assessment is favourable, it will yield positive results for the students. In other words, as stated by Bagheri and Faghih (2012) learners who possess a good feeling of themselves are the ones who perform greater. Additionally, paramount individuals in one's life like friends, fathers, mothers, or instructors form one's opinion about the self. An individual, explicitly or implicitly, accepts the opinions of others and accepts them as truth. In summary, the psychological portrait of oneself is formed by judgments made of the individual himself/herself or by everyone else around him. Others' favorable or negative opinions might help or hurt one's self-esteem.

Regarding the concept of learner autonomy and language-related issues, Nantachaipan (2004) examined the impact of students' autonomy in an English course of oral presentation. A specially designed lesson plan focusing on the utilization of cognitive and metacognitive strategies advanced the skills of oral presentation and learner autonomy. The results revealed that the success of learner autonomy promotion and the advancement of learners' presentation skills. 
In another study, Azimi, Abadi, and Baradaran (2013) tried to identify the association between students' autonomy and vocabulary learning strategies. The participants were 190 male and female students with a diverse language level proficiency. The findings revealed a remarkable positive relationship between autonomous learning and language learning strategies used in an extremely competent group, as well as a significant positive relationship between these two variables in a low competent group, but not as powerful as the association in the advanced group.

\section{Method}

A quasi-experimental design was implemented since it involved a sample of learners who had been chosen voluntarily and had been divided into two groups; an EG and a CG. In this study, blended learning was considered an independent variable, and learner autonomy and self-esteem were the dependent variables.

\subsection{Participants}

The sample of the current study comprised 60 Iranian female intermediate EFL learners who were studying English in language institutes of Ilam, West of Iran. Their age ranged from 16 to 24 and they were selected from among 90 EFL learners after administrating and completing an Oxford Placement Test.

\subsection{Instrumentation}

To gather the required data of the study, three instruments will be used. A learner autonomy questionnaire, a self-esteem questionnaire, and a vocabulary achievement test.

\subsubsection{Learner Autonomy Questionnaire}

The participants' level of autonomy was assessed through administering a questionnaire that was designed by Zhang and Li (2004). The questionnaire included 21 items and is comprised of two parts. The first part contained 11 items which were coded as (A. never B. rarely C. sometimes D. often E. always) and the other 10 items created the second part. All of the items in part 2 should be replied to by selecting one of the five choices following each item. The reliability of the tests was computed by using Cronbach's alpha formula via SPSS. The reported reliability of the vocabulary test was about .75 .

\section{2.2. Self-esteem Questionnaire}

A 25-items questionnaire containing the Foreign Language Self-Esteem Scale provided by Hassan (2001) was employed for the study. This instrument comprised of four diverse components of the foreign language learning self-esteem 1) language capability, 2) real in-class language utilization, 3) in-class correlations, and 4) attitude toward / behavior in the class of foreign language. The Cronbach Alpha Coefficient was (.68) and hence the scale was reliable and ready to be applied. The scale items were rated on a five-point Likert scale (from 1. Strongly Disagree" to 5. Strongly Agree). To interpret learners' self-esteem degree, the following points were considered: a mean self-esteem score of 4 out of 5 (> 80 percent ) was classed as high self-esteem; a mean score of 3 to 4 out of 5 ( 60 to 80 percent) was classed as moderate self-esteem; a mean score of less than 3 out of 5 (60 percent ) was categorized as poor self-esteem. Higher ratings indicated greater self-esteem and vice versa.

\subsubsection{Vocabulary Achievement Test}

To gather the data, a vocabulary achievement test that comprised 25 vocabulary items was used as the pre-post-test. The test was developed to measure the participants' lexical knowledge before and after the instruction. The test was developed by the researcher and it was taken from the Top Notch 2B coursebook (Joan Saslow and Allen Ascher, Second Edition, 2011) that is taught to EFL learners in various areas of the world especially in Iran. The reported reliability of the test was 0.99 utilizing Chronbach's alpha.

\subsection{Procedure}

After selecting the learners, they were randomly divided into two groups; namely the CG and the EG. Each group is composed of 30 learners. Then, in four separate sessions the Oxford placement test, learner autonomy questionnaire, self-esteem questionnaire, and vocabulary achievement test were performed among the participants as the research pre- test. The coursebook that was used for both classes was the Top Notch 2B coursebook (Joan Saslow and Allen Ascher, Second Edition, 2011. Some units of the book were taught to the participants of both groups for 6 weeks (two sessions each week and each session lasted for one hour and a half).

In the EG, the researchers created a blended learning teaching template to help students use the language both inside and outside of the class. In other words, the students in this group learned the target vocabulary items using blended learning methodologies. Interactive multimedia learning tools are designed to encourage students to make new target vocabulary items on their own time. In-class events, on the other hand, the research concentrated on group tasks such as group and group work, creating a positive environment. The $\mathrm{CG}$, on the other hand, learnt the identical vocabulary items through face-to-face and 
traditional methods of training. After 6-weeks of instruction, the learner autonomy questionnaire, self-esteem questionnaire, and vocabulary achievement test were administered to the participants of both groups as post-test. The obtained data were gathered to be analyzed through the appropriate statistical methods.

\subsection{Data Analysis}

To conduct the statistical operations Levene's Test and Covariance were performed using the SPSS, version 25.

\section{Results}

The purpose of this research was to identify the impact of blended learning on Iranian EFL learners' autonomy, self-esteem, and vocabulary achievement. In this part, the results of the data analysis are tabulated and explained.

Table 1

The Mean Distribution of the Participants' Scores of Autonomy, Self-esteem, and Vocabulary Achievement

\begin{tabular}{|c|c|c|c|c|c|}
\hline \multicolumn{2}{|c|}{ Post-test } & \multicolumn{2}{|c|}{ pre-test } & groups & variables \\
\hline Std. Deviation & Mean & Std. Deviation & Mean & & \\
\hline $15 / 01$ & $54 / 08$ & $10 / 41$ & $43 / 37$ & EG & J arner Autonomy \\
\hline $10 / 03$ & $53 / 45$ & $8 / 508$ & $51 / 01$ & CG & Learlet Autorionily \\
\hline $8 / 97$ & $60 / 93$ & $15 / 87$ & $44 / 46$ & EG & Colf nctonm \\
\hline $6 / 55$ & $59 / 23$ & $6 / 89$ & $55 / 13$ & CG & sen-esteem \\
\hline $14 / 62$ & $77 / 86$ & $14 / 94$ & 2051/ & EG & Vocabulary Achievement \\
\hline $15 / 507$ & $44 / 26$ & $16 / 03$ & $36 / 26$ & CG & \\
\hline
\end{tabular}

The results of Table 1 reveals that the mean of the scores of participants' Autonomy in the EG was less than $(M=43.37)$ the mean of participants scores in the $C G(M=51.01)$ at the stage of the pre-test. Furthermore, the mean of participants Autonomy scores in the $E G$ was more than $(M=54,08)$ the mean of participants' scores in the $C G(M=53.45)$ after project-based instruction at the stage of the post-test. It is said, that the mean of the participants' autonomy scores in the EG was less than the CG. But, after receiving the instruction through blended learning, the mean of the scores of the EG was more than the CG.

In addition, the mean of the scores of participants' self-esteem in the EG was less than $(M=44.46)$ the mean of participants' scores in the CG $(M=55.13)$ at the stage of the pre-test. Furthermore, the mean of participants` self-esteem scores in the EG was more than $(M=60.93)$ the mean of participants' scores in the $C G(M=59.23)$ after project-based instruction at the stage of the post-test.

Moreover, the mean of the scores of participants' vocabulary development in the $E G$ was more than $(M=51.02)$ the mean of participants' scores in the CG $(M=36.26)$ at the stage of the pre-test. Furthermore, the mean of participant's vocabulary achievement in scores in the $E G$ was more than $(M=77.86)$ the mean of participants' scores in the $C G(M=44.26)$ after projectbased instruction at the stage of the post-test.

Table 2: The Kolmogorov-Smirnov Test of the Variables of the Study

\begin{tabular}{|c|c|c|c|c|c|}
\hline Significance & The Kolmogorov-Smirnov Test & $\begin{array}{c}\text { Freque } \\
\text { ncy }\end{array}$ & Groups & Variables & Tests \\
\hline $0 / 844$ & $0 / 615$ & 30 & EG & \multirow{2}{*}{ Learner Autonomy } & \multirow{6}{*}{$\begin{array}{l}\text { Pre- } \\
\text { test }\end{array}$} \\
\hline $0 / 767$ & $0 / 666$ & 30 & CG & & \\
\hline $0 / 086$ & $1 / 25$ & 30 & EG & \multirow{2}{*}{ Self-esteem } & \\
\hline $0 / 952$ & $0 / 518$ & 30 & CG & & \\
\hline $0 / 88$ & $0 / 588$ & 30 & EG & \multirow[t]{2}{*}{ Vocabulary Achievement } & \\
\hline $0 / 328$ & $0 / 949$ & 30 & CG & & \\
\hline $0 / 558$ & 0/792 & 30 & EG & \multirow{4}{*}{ Learner Autonomy } & \multirow{6}{*}{$\begin{array}{l}\text { Post- } \\
\text { test }\end{array}$} \\
\hline $0 / 984$ & $0 / 46$ & 30 & CG & & \\
\hline $0 / 984$ & $0 / 636$ & 30 & EG & & \\
\hline $0 / 813$ & $0 / 87$ & 30 & CG & & \\
\hline $0 / 436$ & $1 / 07$ & 30 & EG & \multirow[t]{2}{*}{ Vocabulary Achievement } & \\
\hline $0 / 868$ & $0 / 597$ & 30 & CG & & \\
\hline
\end{tabular}


As Table 2 reveals, the significance was more than $0 / 05$; thus, it can be concluded that the data of the above Table had the normal distribution.

\subsection{Addressing the First Research Question}

To answer the first research question, the following tables must be consulted.

Table 3: The Results of Levene's Test of the Equality of the Variances

\begin{tabular}{cccc}
\hline (Sig) & df2 & df1 & $F$ \\
\hline $0 / 059$ & 58 & 1 & 3.71 \\
\hline
\end{tabular}

The above table shows the results of Levene's Test. As the amount of significance $(\operatorname{sig}=0.059)$ was more than the error level of 0.05 , thus the variance of both groups was equal.

Table 4: Investigating the Results of the Covariance Analysis of the Research Variable

\begin{tabular}{ccccccc}
\hline $\begin{array}{c}\text { Partial Eta } \\
\text { Squared }\end{array}$ & $($ Sig) & $\begin{array}{c}\text { Fisher test } \\
(\mathrm{F})\end{array}$ & $\begin{array}{c}\text { Mean Square } \\
(\mathrm{MS})\end{array}$ & $(\mathrm{df})$ & $\begin{array}{c}\text { Type III Sum } \\
\text { of Squares } \\
(\mathrm{SS})\end{array}$ & Source \\
\hline $0 / 799$ & $0 / 000$ & $112 / 99$ & $3779 / 08$ & 2 & $7558 / 17$ & Corrected Model \\
$0 / 01$ & $0 / 452$ & $0 / 575$ & $19 / 21$ & 1 & $19 / 21$ & Intercept \\
$0 / 798$ & $0 / 000$ & $225 / 84$ & $7553 / 66$ & 1 & $7553 / 66$ & Pre-test \\
$0 / 389$ & $0 / 000$ & $36 / 27$ & $1313 / 34$ & 1 & $1213 / 34$ & Group \\
& & & $33 / 44$ & 57 & $1906 / 41$ & Error \\
& & & & 60 & $182706 / 29$ & Total \\
& & & & 59 & $9464 / 58$ & Corrected Total \\
\hline
\end{tabular}

Table 4 reveals that based on the significance of $0.000(\mathrm{sig}=0.000)$ and the amount of the computed $F(F=225.48)$, instruction through blended learning was the main cause of a difference that can be seen in participants' autonomy scores at the stages of pre and post-test. Moreover, Eta square demonstrated that instruction through blended learning had been led to an increase of 0.79 percent in participants' autonomy scores. As the amount of significance was 0.000 , it is concluded that the mean of the participants' autonomy scores was different in the stages of pre-test and post-test. Thus, it can be inferred that instruction through blended learning had a significant influence on participants' level of autonomy.

\subsection{Addressing the Second Research Question}

To reach a logical answer to the $2^{\text {nd }}$ research question, one needs to look at the following tables.

Table 5: The Results of Levene's Test of the Variances Equality

\begin{tabular}{cccc}
\hline (Sig) & df2 & df1 & $F$ \\
\hline 0.094 & 58 & 1 & 2.901 \\
\hline
\end{tabular}

Results of the above Table show that ss the amount of significance (sig=0.094) was more than the error level of 0.05 ; therefore, the variance of both groups was equal.

Table 6: Examining the Results of the Covariance Analysis of the Research Variable

\begin{tabular}{ccccccc}
\hline $\begin{array}{c}\text { Partial Eta } \\
\text { Squared }\end{array}$ & $($ Sig) & $\begin{array}{c}\text { Fisher test } \\
(\mathrm{F})\end{array}$ & $\begin{array}{c}\text { Mean Square } \\
(\mathrm{MS})\end{array}$ & $(\mathrm{df})$ & $\begin{array}{c}\text { Type III Sum } \\
\text { of Squares } \\
(\mathrm{SS})\end{array}$ & Source \\
\hline & & & & 2 & $402 / 202$ & Corrected Model \\
$0 / 111$ & $0 / 035$ & $3 / 55$ & $201 / 101$ & 1 & $8265 / 501$ & Intercept \\
$0 / 719$ & $0 / 000$ & $146 / 116$ & $8265 / 501$ & 1 & $358 / 85$ & Pre-test \\
$0 / 100$ & $0 / 015$ & $6 / 344$ & $358 / 852$ & 1 & $187 / 53$ & Group \\
$0 / 055$ & $0 / 074$ & $3 / 315$ & $187 / 53$ & 57 & $3224 / 382$ & Error \\
& & & $56 / 56$ & 60 & 220227 & Total \\
& & & & 59 & $3626 / 583$ & Corrected Total \\
\hline
\end{tabular}


By taking into account the significance of $0.015(\mathrm{sig}=0.015)$ and the amount of the computed $F(F=6.344)$, the mean of the participants' self-esteem scores was different at the phases of pre-test and post-test. Eta square showed that was 0.1 that reveals the amount of the effectiveness of the pre-test on the post-test of the self-esteem was very small. It means that the participants'self-esteem scores did not differ in both stages of the pre-test and post-test. The mean of the participants selfesteem scores in phases of pre-test and post-test was similar to each other since the amount of significance (Sig=0.074) was more than the error level of 0.05 . Therefore, it can be deduced that instruction via blended learning had no significant influence on participants' self-esteem.

\subsection{Addressing the Third Research Question}

Tables 7 and 8 are needed to be consulted to reach a reasonable answer to the third research question:

Table 7: Levene's Test of the Assumption of Variances Equality

\begin{tabular}{cccc}
\hline (Sig) & df2 & df1 & $F$ \\
\hline 0.005 & 58 & 1 & 8.498 \\
\hline
\end{tabular}

The results of the above Table reveal that since the amount of significance $(s i g=0.005)$ was less than the error level of 0.05 ; therefore, the variance of both groups was not identical.

Table 8: Surveying the Results of the Covariance Analysis of the Research Variable

\begin{tabular}{|c|c|c|c|c|c|c|}
\hline $\begin{array}{c}\text { Partial Eta } \\
\text { Squared }\end{array}$ & (Sig) & $\begin{array}{c}\text { Fisher } \\
\text { test } \\
(\mathrm{F})\end{array}$ & $\begin{array}{c}\text { Mean Square } \\
\text { (MS) }\end{array}$ & $(d f)$ & $\begin{array}{l}\text { Type III } \\
\text { Sum of } \\
\text { Squares } \\
\text { (SS) }\end{array}$ & Source \\
\hline $0 / 858$ & $0 / 000$ & $171 / 989$ & $12913 / 927$ & 2 & $25827 / 854$ & Corrected Model \\
\hline $0 / 509$ & $0 / 000$ & $59 / 033$ & $4432 / 538$ & 1 & $4432 / 538$ & Intercept \\
\hline $0 / 675$ & $0 / 000$ & $118 / 444$ & $8893 / 454$ & 1 & $8839 / 454$ & Pre-test \\
\hline \multirow[t]{4}{*}{$0 / 57$} & $0 / 000$ & $75 / 634$ & $5679 / 005$ & 1 & $5679 / 005$ & Group \\
\hline & & & $75 / 086$ & 57 & $4279 / 77$ & Error \\
\hline & & & & 60 & 253856 & Total \\
\hline & & & & 59 & $30107 / 733$ & Corrected Total \\
\hline
\end{tabular}

As the above table shows, the amount of the meaningfulness level of the pre-test of vocabulary achievement was 0.000 (Sig= 0.000 ) and the amount of the calculated $F$ was $118.44(F=118.44)$. Thus, it can be said that the participants' scores of vocabulary achievement at the stages of pre and post-test were different. This refers to the point that instruction through blended learning creates some changes in participants' vocabulary achievement scores at the pre-test and post-test stages. Eta square demonstrated that instruction through blended learning has been led to an increase of 0.67 percent in participants' vocabulary achievement scores. As the amount of significance was 0.000 , it is concluded that the mean of the vocabulary achievement scores of the participants of both groups was different in the stage of post-test. Hence, we can make a conclusion that instruction through blended learning had a significant influence on participants' vocabulary achievement.

\section{Discussion}

As mentioned earlier, identifying the effect of blended learning on Iranian EFL learners' autonomy, self-esteem, and vocabulary achievement was the main goal of this research. The results showed that instruction through a blended learning approach had a significant influence on participants' level of autonomy and vocabulary achievement. In addition, based on the results; blended learning had no remarkable impact on learners' self-esteem.

Regarding the usefulness of blended learning on Iranian EFL learners' vocabulary achievement, the results obtained are agreeable with the results of Djiwandono (2009), Vasbieva, Klimova, Agibalova, Karzhanova, and Bírováe (2016), Khalili, Tahririan, and Bagheri (2015). Moreover, the result of this study is not congruent with the results of a study performed by Tosun (2015) who examined the impact of the strategy of blended learning on teaching vocabulary and the learners' attitudes of the approach of blended learning in vocabulary learning. The findings demonstrated that there was no significant difference between the two groups about their vocabulary knowledge receiving a blended approach for 6 -weeks.

In addition, the result is in contrast with the result of Bagheri, Roohani, and Nejad Ansari (2012), which found that there existed no significant difference between CALL-based and non-CALL-based methods of vocabulary teaching. 
Regarding the influence of blended learning on Iranian EFL learners' autonomy, the outcomes revealed that the participants' level of autonomy was positively affected by blended learning. The mean of the EG participants' autonomy scores at the stage of pre-test was $47.37(\mathrm{M}=57.37)$ while it was $51.01(\mathrm{M}=51.01)$ in the CG. But, after instruction through the approach of blended learning, the means of the autonomy scores of the EG participants was $54.08(M=54.08)$ whereas it was $53.45(M=53.45)$ in the CG. As it was seen, the participants' mean of autonomy scores was increased after blended learning instruction. Therefore, it can be said that the enhancement that was emerged in the autonomy scores of the EG was the result of administering the blended learning approach in the process of teaching. This result is in line with the results of Farivar and Rahimi (2015) who made an effort to examine the impact of CALL on the Iranian EFL learners' autonomy. The findings of their study showed that the application of CALL had a significant effect on the progression of participants' autonomy. The results are also congruent with Meri's (2012) study. Meri identified the correlation between learner autonomy and CALL in the Turkish context. In other words, CALL advanced learner autonomy.

As mentioned, the results indicated that blended learning had no significant effect on learners' self-esteem. There was no significant difference between the self-esteem scores of the participants of both groups in the phase of post-test. Therefore, it can be concluded that learners' self-esteem was not influenced by the blended learning instruction positive way.

\section{Conclusion}

In conclusion, it can be said that vocabulary instruction through a blended learning approach could be useful and effective to assist EFL learners to promote their knowledge of vocabulary. Moreover, if digital instruments are selected under the needs and interests of learners, the learning outcomes will be maximized. To create the optimal selection of online tools and activities for each group of learners, a requirements analysis should be performed. When properly applied and performed, blended learning can help the process of vocabulary development by increasing the amount of learning compared to in-class learning. Also, it is possible to infer that blended learning should still be supplemented by intense activities that enhance the storage and retrieval of newly learnt vocabulary. A strategy in which learners are allowed to practice recall of target vocabulary on their own is most likely less efficient and successful than one in which the instructor facilitates the recall in either a face-to-face session or an online session specifically prepared and geared for that objective.

Even though, as the researcher noticed, the respondents were pleased with the recommended blended learning technique for teaching vocabulary and preferred it to traditional classroom-based learning, the instruction through the blended learning approach did not have a significant impact on their self-esteem. The participants' self-esteem did not exchange after receiving instruction through based learning, therefore it can be concluded that the participants' degree of self-esteem did not enhance. Moreover, as instructors are the most significant variables in upgrading the efficiency of the EFL learning process and the primary companions to students in this regard, suggestions here concern the English language teachers in Iran. As a first step in enhancing learners' self-esteem, instructors must become knowledgeable of what self-esteem is, what its elements and sources are, the indicators and repercussions of low self-esteem, and how self-esteem-boosting technologies might be used -in the language curriculum. Teachers must realize that building learners' self-esteem should be founded on legitimate frameworks and appropriate programs that give practical guidelines and guidelines for dealing with students' self-esteem, such as those presented by Schiraldi (2001) and Norton (2001). (2015).

In conclusion, based on the findings, the usefulness of the blended learning approach on participants' autonomy was confirmed. The post-test results revealed that the EG outperformed the CG. As a result, it is reasonable to conclude that the deployment of the blended learning technique aided the EG autonomy more than the CG. When the other sources of language knowledge, like CALL materials, are available for learners, they become more independent. In this circumstance, instructors should reassess linguistic approaches and fearlessly go down from the platform to the learners' computer station. They must provide learners with appropriate information and advice for their self-directed learning, aid them in promoting their self-directed learning practices, and teach them to be true independent learners. The present study has some implications for educational institutions, EFL teachers, learners, and curriculum developers. The educational institutions should provide the needed infrastructure to utilize electronic learning in the process of education. Teachers and learners should be stimulated to apply electronic communication instruments to facilitate communication between both parties. The teacher should encourage learners to use the approach of blending learning to be independent and autonomous learners. Curriculum designers should know that the design of the English language curriculum should meet the learners' interests and requirements. Moreover, EFL teachers, learners, and curriculum developers should obtain awareness on how to put learners' self-esteem into EFL practice. 


\section{References}

[1] Alshwiah, A. A. S. (2009). The effects of a blended learning strategy in teaching vocabulary on premedical students' achievement, satisfaction, and attitude toward the English language (Published master thesis). Arabian Gulf University, Bahrain.

[2] Apter, T. (1998). The Confident Child. New York: Bantam Books.

[3] Azimi M., Abadi, E., \& Baradaran, A. (2013).The Relationship between Learner Autonomy and Vocabulary Learning Strategies in Iranian EFL Learners with Different Language Proficiency Level. International Journal of AppliedLinguistics \& English Literature, 2(3), $176-185$.

[4] Bagheri, E., Roohani, A., \& Nejad Ansari, D. (2012). Effect of CALL-based and non-CALL-based methods of teaching on L2 vocabulary learning. Journal of Language Teaching and Research, 3 (4), 744-752.

[5] Bagheri, M. S., \& Faghih, M. (2012). The Relationship between Self-esteem, Personality Type and Reading Comprehension of Iranian EFL Students. Theory and Practice in Language Studies, 2(8), 1641-1650.

[6] Bocanegra, A., \& Haidi, A. W. (1999). Language learner autonomy in practice: possibilities in a foreign language situation. Revista Alicantina de Estudios Ingleses, 12, 7-17.

[7] Branden, N. (1985). Honoring the self; self-esteem and personal transformation. New York: Bantam Books.

[8] Branden, N. (1999). The Art of Living Consciously. New York: Bantam Books.

[9] Djiwandono, P. I. (2009). Enhancing vocabulary learning through written productive task: a study of pre-intermediate EFL learners at Ma Chung University. Paper presented at the Seminar of Foreign Language Learning and Teaching, Bangkok, Thailand.

[10] Farivar, A., \& Rahimi, A. (2015). The Impact of CALL on Iranian EFL Learners' Autonomy. Procedia - Social and Behavioral Sciences, 192, 644 649

[11] Graham, C. R. (2006). Blended learning systems, e Handbook of Blended Learning, Pfeiffer Publisher, San Francisco, CA, USA,

[12] Grandin, T. (2002). Asperger's and self-esteem: Insight and hope through famous role models. Arlington, TE: Future Horizons.

[13] Hassan, B. A. (2001). The Relationship of Writing Apprehension and Self-Esteem to the Writing Quality and Quantity of EFL University Students. Mansoura Faculty of Education Journal, 39, 1-36.

[14] Khalili, S., Tahririan, M. H., \& Bagheri, S. (2015). Vocabulary Instruction through Blended Learning and Multimedia Software in Iranian ESP Classes. Journal of English Language Teaching and Learning, 16, 37-54.

[15] Khazaei, S., \& Dastjerdi, H. V. (2011). An Investigation into the Impact of Traditional vs. Blended Teaching on EFL Learners' Vocabulary Acquisition: M-learning in Focus. International Journal of Humanities and Social Science, 1(15), 202-207.

[16] Meri, S. (2012). Autonomous Computer-Assisted Language Learning: Turkish Primary School Students' Perceptions of Dined Software. International Conference "ICT for Language Learning". 5th edition.

[17] Mousa, A., \& Mubarak, A. (2005). E-learning, Foundations and Applications, Data Network Corporation, Riyadh, Saudi Arabia.

[18] Murk, C. (1999). Self-esteem research, theory, and practice. New York: Springer.

[19] Namaziandost, E., \& Çakmak, F. (2020). An account of EFL learners' self-efficacy and gender in the Flipped Classroom Model. Education and Information Technologies, 25(2), 4041-4055. https://doi.org/10.1007/s10639-020-10167-7

[20] Namaziandost, E., Nasri, M. \& Ziafar, M. (2019). Comparing the impacts of various inputs $(I+1 \& \mid-1)$ on pre-intermediate EFL learners' reading comprehension and reading motivation: the case of Ahvazi learners. Asian. J. Second. Foreign. Lang. Educ, 4(13), 1-20. doi:10.1186/s40862-019-0079-1.

[21] Namaziandost, E., Rezvani, E., Polemikou, A. (2020). The impacts of visual input enhancement, semantic input enhancement, and input flooding on L2 vocabulary among Iranian intermediate EFL learners. Cogent Education, 7(1). DOI: 10.1080/2331186X.2020.1726606

[22] Nantachaipan, A. (2004). Promoting English Oral Presentation Skills of Undergraduate Students Through Autonomous Learning Approach. Master's Thesis, Department of Teaching English as a Foreign Language, Faculty of Education, Chiang Mai. University.Nuttall, C. (1996). Teaching Reading Skills in a Foreign Language (2nd Ed.). Oxford: Heinemann.

[23] Norton, B. (2015). Extreme Confidence: A Comprehensive Guide for Increasing Self-Esteem and Confidence. Canada: CreateSpace Independent Publishing Platform.

[24] Schiraldi, G. R. (2001). The Self-Esteem Workbook. Oakland, USA: New Harbinger Publications.

[25] Stevick, E. (1990). Humanism in language teaching. Oxford, UK: Oxford University Press.

[26] Stout, M. (2001). The feel-good curriculum: The dumbing down of America's kids in the name of self-esteem. USA: Da Capo Press.

[27] Tosun, S. (2015). The effects of blended learning on EFL students' vocabulary enhancement. Social and Behavioral Sciences, $199,641-647$.

[28] Vasbievaa, D., Klimova, l., Agibalova, E., Karzhanova, N., \& Bírová, J. (2016). Enhancement of Students' Vocabulary Learning Through a Blended Learning Approach. lejme Mathematics Education, 11(5), 1195-1203.

[29] Zhang, H., Song, W., \& Burston, J. (2011). Reexamining the effectiveness of vocabulary learning via mobile phones. The Turkish Online Journal of Educational Technology, 10, 203-214.

[30] Zhang, L. X., \& Li, X. X. (2004). A comparative study on learner autonomy between Chinese students and west European students. Foreign Language World, 4, 15-23. 